\title{
Barron's Survey: The World's Best CEOs
}

\author{
Greg Filbeck, CFA, FRM, CAIA \\ Professor of Finance \\ Black Family Professor of Insurance and Risk Management \\ Sam and Irene Black School of Business \\ Penn State Erie, 286 Burke, Erie, PA 16563, USA \\ Tel: 1-814-898-6549 E-mail: mgf11@psu.edu
}

\author{
Raymond Gorman \\ Professor of Finance \\ School of Business, Miami University \\ Oxford, OH 45056, USA
}

Tel: 1-513-529-3631 Fax: 1-513-529-6992Ｅ-mail: gormanrf@muohio.edu

\author{
Xin Zhao \\ Associate Professor of Finance \\ Sam and Irene Black School of Business \\ Penn State Erie, Erie, PA16563, USA \\ Tel: 1-814-898-6256 E-mail: xuz12@psu.edu
}

Received: February 11, 2012

doi:10.5430/afr.v1n1p18
Accepted: February 28, 2012

Published: May 15, 2012

URL: http://dx.doi.org/10.5430/afr.v1n1p18

\begin{abstract}
We examine the abnormal returns around the publication dates of the Barron World's Best CEOs issues along with longer-term, risk-adjusted performance. One specific focus of the paper is whether the inclusion in the Barron's survey leads to an increase in positive "affect" of the firms as suggested by Statman, Fisher, and Anginer (2008) in the case of Fortune's most admired firms. In addition, we explore the effect of the listing on the compensation of CEOs included in the ranking. We find a negative share price response to the release of Barron's list. The Best CEOs portfolio return is indistinguishable from the S \& P 500 on a longer-term basis, and it underperformed against constructed matched samples, with no differences in risk adjusted returns. Profitability did not increase for selected firms in the post-announcement period and no patterns exist in terms of changes in CEO compensation are associated with the CEO's inclusion in Barron's list.
\end{abstract}

JEL codes G11 Portfolio Choice • Investment Decisions G14 Information and Market Efficiency • Event studies

Keywords: Shareholders wealth, Event study, Investment strategy

\section{Introduction}

The importance of leadership for the modern corporation is a recurring theme in the popular business literature. While Covert and Sattersten (2009) list only ten books primarily focusing on leadership in their best-selling book on the 100 Best Business Books of All Time, a closer look at their list reveals that leadership is a dominant theme in many of the other ninety books. For example in Good to Great - listed as a strategy book by Covert and Sattersten - Collins (2001) identifies the presence of a level 5 leader as an essential ingredient in companies that made the move from good to great. Collins defines a level 5 leader (executive) as one whom "builds enduring greatness through a paradoxical blend of humility and professional will” (p. 20). Similarly, Ware, Michaels and Primer (2004) contend that the presence of a strong corporate culture as established by effective leaders is a key ingredient in corporate success. While these cultures 
may vary greatly, they all have in common corporate leadership that communicates ideals to employees and maintains consistency in this message regardless of economic events impacting the company.

Intertwined in questions concerning the relationship between the identification of the best CEOS and the subsequent corporate and individual benefits is the issue of what role the media plays in influencing this relationship. Fang and Peress (2009) investigate whether media outlets have the ability to influence portfolio returns. Their results indicate that while the media coverage helps explain the cross-sectional distribution of stock returns, firms receiving no media attention actually perform better those who do.

In this paper, we use Barron's annual "World's Best CEOs" listing as a proxy for superior company leadership to investigate whether superior leadership leads to superior financial performance. Barron's annual "World's Best CEOs" made its debut in the March 27, 2005 issue. The selection of the 30 top leaders was based on earnings growth, stock performance, leadership strength and industry stature, competitive challenges faced in their respective businesses, and job tenure of at least three years. Barron's makes it clear that their selections are subjective and open for debate. They also acknowledge a bias exists toward those firms that have exhibited solid earnings growth and greater reliance on stock market performance for CEOs who have served for longer time periods. Thus, the criteria for selection includes both objective data (financial and stock-market performance), but also subjective data (leadership, industry stature, and reputation). The initial survey featured 22 US-based and 8 foreign firms, with the subsequent surveys in 2006 and 2007 containing 20 US-based and 10 foreign firms. While some turnover exists on the list each year, a remarkably high retention rate exists with 20 of the 30 firms listed in both 2005 and 2006 returning the following year for a 67 percent retention rate. Commentary is provided each year as to why each CEO was selected, and why others were not. In 2007, the retention/replacement issue was formalized with a table indicating specifically the reason why the CEOs were removed from the list, along with a rationale as to why new CEOs were added. For example, in 2007, Satoru Iwata of Nintendo was added because Barron's denoted that "Wii (was) a winner; stock soars," while Anne Mulcahy of Xerox was removed because "momentum may be flagging."The comments in a given year may consist of a mix of historical information (e.g., weak earnings), current assessments (e.g., profit pressures), and forward projections (e.g., movements into new markets could lead to new opportunities).

While the intent of the editors is not to offer advice to their readership on the merits of each of these firms as potential investments, certainly the editors were commending these firms for being led by extraordinary leaders. Yet, except for vague references to the admittedly subjective selection criteria (even the performance-based criteria were not quantified), specific benchmarks, other than a minimum of three years of service as CEO, are not identified within each category. The survey has evolved with changes in the economic environment. For instance, the 2010 survey focused on the ability for executives to keep their companies out of trouble and to expand in the recession through profitable acquisitions.

As a media outlet, Barron's is a powerful player within the financial information world. According to Barron's media kit (http://www.barronsmag.com/docs/circulation/ABC_PubReport_Dec2010.pdf), Barron's enjoys a paid and verified circulation of 304,807 copies as of December 31, 2010.In addition, Barron's web demographics indicate that the average household wealth of users of their website is $\$ 3,401,000$ with 52.1 percent of fund managers and 41.1 percent of financial advisors/planners part of their online demographics (http://www.barronsmag.com/advert_audience.html). While the rationale for selection often contains a mix of an acknowledgement of recent performance along with future possibilities, as a media outlet, it offers a showcasing of these firms for efforts that the general public may have overlooked or not considered in the context of superior firm leadership. Thus, Barron's serves as a powerful voice for financial professionals and high net worth individuals who may be influenced by articles that it publishes. One might be tempted to infer that the identification of the best CEOs by Barron's may be viewed by the market as a positive signal of the future prospects of the CEOs' companies and as a predictor of future increases in compensation for the selected CEOs.

In this paper, we examine both the announcement effect associated with being named to (or being removed from) the annual listing and the long-term holding period performance of the selected firms. Risk-adjusted performance measures as well as comparisons against appropriate benchmarks are also presented. We also explore whether positive differences exist between selected firms and non-selected firms in terms of operating performance and subsequent CEO compensation. Our study finds that the Best CEO sample generates an initial negative reaction in the market with longer-term returns indistinguishable from the broad market and inferior to matched samples. No significant differences exist in risk-adjusted performance, and firms failed to have improved financial profitability after selection compared to their non-selected counterparts. We find little evidence that a company whose CEO has been identified as having one of the best leads to superior financial performance or that the CEO benefits from increased compensation. 
In the next section, we review the relevant literature pertaining to the link between managerial quality and financial performance with particular emphasis on studies that measure management quality on the basis of survey data. Our sample data, methodology and hypotheses are presented in section III, and the results of our analysis are contained in section IV. Concluding remarks are offered in the final section.

\section{Literature Review}

Understanding the qualities of good management has long been a topic in the management literature. More recently, especially in the wake of corporate scandals such as Enron and Tyco, the finance profession has begun to take a closer look at the quality of management and financial performance. Jennings (2005) argues that hiring managers with courage and a strong moral compass will do more to eliminate corporate misbehavior than will additional regulation.

At a company-wide level, Statman, Fisher, and Anginer (2008) hypothesize that affect, the unconscious feeling regarding the "goodness" or "badness," of a corporation may play a role in the prices and returns from stocks that may be admired for their positive qualities or despised for their less desirable characteristics. Specifically, in the development of a behavioral asset-pricing model, they argue that stocks with negative affect result in higher subjective risk and require higher returns in order to compensate for this behavioral-based risk.

In their analysis of Fortune's most admired corporations, they find that spurned stocks (those performing poorly in Fortune's ranking) actually outperformed those stocks that were admired. They further posit that this may be a consequence of the stock prices of the admired firms rising as a result of their being identified as "admired" firms thus setting them up for lower returns in the future. Similarly, the identification of firm that are least admired increases their negative affect, lowering their stock prices and setting the stage for higher returns. Statman, et al. hypothesize that affect is reflected in the market capitalization and book-to-market factors of the Fama and French (1993) 3- and 4-factor models.

In contrast, Shefrin and Statman (1993) regress a measure of the quality of management against the shareholder returns based on the 1992 Fortune survey and find a statistically significant level of correlation between the two variables. This result is consistent with the hypothesis that an association exists between the quality of a company's management and its long-term investment value, a result inconsistent with that of Statman, et al.

Anderson and Smith (2006) test whether a company's positive qualities are already reflected into a company's stock price. Evaluating the stock performance of the most admired companies in Fortune magazine's annual survey between 1983 through 2004, they find that a portfolio of admired stocks outperformed the market by a substantial and statistically significant margin, a result inconsistent with the market efficiency. They conclude that in order to beat the market, investors must focus on the intangibles of a company, which would include being recognized as admirable by Fortune.

Shefrin and Statman (1995) also analyze the Fortune surveys of company reputations. They find evidence that survey respondents rank large companies with low book-to-market ratios as though they believe they are good companies. They note that this is incongruent with empirical evidence suggesting that good stocks are stocks of small companies with high book-to-market ratios. Shefrin and Statman also find that respondents rank stocks as if they are indifferent to beta. They argue that the belief that good stocks are the stocks of good companies underlies the superior performance of high-book-to-market ratio, small company stocks. Hammond and Slocum (1996) link financial performance to reputation. They posit that, by improving financial results, a firm can directly improve its reputation. Demaree (1993) finds that financial results may not be enough to ensure a strong reputation and that strong management also plays a role in improving reputation.

Studies that deal directly with Fortune's other corporate awards are numerous. Filbeck, Gorman and Preece (1997) and Vergin and Qoronfleh (1998) study the performance of Fortune's "Most Admired Firms."Both studies find that the most admired firms do indeed outperform the market.

Sarkar and Almudhaf (2009) analyze the share price response of being named to the Forbe's 400 Best Big Companies list. They find that holding a portfolio of the entire Forbe's list does show statistically significant abnormal returns, but this performance is driven by the bottom ten ranked firms, which produce a 56 percent return in a 36-month post-publication holding period.

Canella and Hambrick (1993) analyze the effect of the departure by top executives of acquired firms have on the firm's performance. They find that improved post-acquisition performance occurs when departing executives are given a top management role in the newly combined firm. Their results suggest top management, and their leadership abilities, are intangibles that have an impact on a company's value. Chang, Dasgopta, and Hilary (2010) confirm this finding and show that the stock price reaction upon CEO departure is negatively related to the firm's prior performance and to the CEO's prior pay. They argue that the CEO impacts firm value beyond firm's assets or other more tangible factors. 
To determine what type of managerial style produces success, Shea (1999) uses a 3-factor, repeated-measures experiment testing the effect of leadership style (charismatic, structuring, and considerate) on performance improvement on a manufacturing task. She finds that considerate leadership appears to have an immediate, but not a long-lasting, effect on the performance. In addition, Shea finds that charismatic leadership has a delayed impact, and structuring leadership (business-like, neutral, and factual) appears to have had no effect.

Zingales (2000) shows human capital is becoming a greater determinant of firm value. For firms that were formerly privately held, Adams, Almeida, and Ferreira (2005) find that when the firm's founder retains the CEO title (resulting in more concentrated firm decision making), greater performance volatility occurs. Fee (2003) discovers that external labor opportunities for senior executives are correlated with higher shareholder returns.

By examining the financial performance of firms associated with Barron's Best CEOs survey, we hope to gain a better understanding of how performance relates specifically to leadership effectiveness and positive affect. In our study, we attempt to control for affect by using company size and market to book values as proxies for affect as suggested by Shefrin and Statman (1995) and Statman, et al. (2008).

\section{Hypotheses}

Our first research question is to whether the announcement of a firm's CEO being selected to the World's Best CEO list is perceived by the market as having value. While the market has access to who leads each corporation, the market does not know which of these leaders are considered the best at their jobs. Once this information is revealed, there is the possibility that the market reassesses the future prospects of the affected firms. Assuming that the criteria Barron's uses to create its rankings are considered to be attributes associated with producing shareholder value and thus resulting in a positive market reaction, we argue that there should be an upward appraisal of the firm's stock price at the time of the announcement. Thus, our first hypothesis is as follows:

Ha1: There will be a positive share price response to the announcement for firms whose CEOs are named to Barron's Best CEOs list.

Our second research question is to whether the announcement of a firm's CEO being selected to the World's Best CEO list is perceived by the market place as having longer-lasting value. Assuming that the criteria Barron's uses to create its rankings are considered to be attributes associated with long-term success, we argue that the holding period returns associated with a firm having their CEO listed on the World's Best CEO list should exceed that of an appropriate benchmark. Thus, our second hypothesis is as follows:

Ha2: Holding period returns associated with firms whose CEOs are named to Barron's World's Best CEO list will exceed those of appropriate benchmarks on a raw and risk-adjusted basis.

Our third research question is to whether the announcement of a firm's CEO produces superior profitability or operating performance. Assuming that the criteria Barron's uses to create their rankings are considered to be attributes associated with better managed firms, enhanced operating performance would be expected. Thus, our third hypothesis is as follows:

Ha3: Firms with CEOs selected the World's Best CEOs will experience higher accounting profitability compared to firms that are not selected.

Our fourth research question explores the possibility that selected CEOs are being acknowledged more for their ability to lead during difficult times or for being able to take advantage of opportunities during the best times. If being a member of the "Best CEOs" plays an important role in the stock performance, then these CEOs may take advantage of opportunities during good times, and may better manage new risks during very bad times. If so, we might imagine that on days when the whole market is subject to either big upturns or downturns, a portfolio of companies managed by good CEOs would outperform a portfolio of companies with less highly-regarded CEOs. Thus, our fourth hypothesis is as follows:

Ha4: Firms with CEOs selected the World's Best CEOs will experience superior share price performance during periods of extreme market conditions.

Our fifth research question is whether being selected as a Best CEO by Barron's leads to higher compensation? Meulbroek (2001) notes three functions of executive compensation systems: (1) to compensate managers for completed work, (2) to reduce principal-agent costs and (3) to retain the manager. Following the announcement of a company's CEO being recognized as one of the world's best, we would expect that there will be increased demand for the CEO's services and thus additional compensation to retain the CEO. To investigate this issue, we look at CEO compensation before and after the announcements. Assuming firms perceive that the selection of their CEO to the World's Best CEO 
list as valuable, firms should increase their overall compensation packages for selected CEOs to a greater extent than what would be observed for non-selected CEOs. Thus, our fifth hypothesis is as follows:

Ha5: CEOs selected the World's Best CEOs will experience greater compensation packages compared to non-selected CEOs.

\section{Sample and Methodology}

Standard event methodology is used to generate abnormal returns pertaining to the announcement of inclusion on the World's Best CEO list and test our first hypothesis. The Best CEOs sample in this study is based on Barron's annual survey, the first of which was published in the March 28, 2005 issue. (Note 1) To be included in the sample, the firm must meet the following criteria:

1) The sample firms must have return records on the Center for Research on Stock Prices (CRSP) Daily Combined Return File 326 days immediately prior to the announcement date.

2) The sample firms must have return records on the CRSP Daily Combined Return File after the announcement date until the next press release date of next survey(Note 2).

3) The firm must have complete data on Standard and Poor's Research Insight ${ }^{\circledR}$.

The annual World's Best CEOs for this study, along with their respective ranks each year are listed in Table 1.Across the six years of the survey from 2005 - 2010, there were 138 viable announcements for the annual listing of the top 30 companies.

(Insert Table 1 here)

In order to test our second hypothesis, we compare holding period returns of the Best CEO firms to the performance of the S\&P 500 Index, as well as to our three alternative matched benchmark portfolios, described in the next paragraph. We calculate both the cumulative raw returns and risk-adjusted returns. Also, we test our long-run stock performance. We also conduct sensitivity tests of our results by calculating the accounting performance one year and three years after the announcement.

We use three matched portfolios as our benchmark and compare them with the Best CEO firms:

- Size and BE/ME match: matched based on previous year end's market capitalization and book-to-market value of equity (BE/ME) ratio.

- Barron match 1: we use Barron's selection criteria and create a matched sample based on the average of the previous five years' EPS growth rate and the previous five years' annual stock returns.

- Barron match 2: we use Barron's selection criteria and create a second matched sample based on the average the previous five years EPS growth rate, the past 5 years annual stock returns, and service years when the CEO is selected as the Best CEO.

We retrieve the previous year-end market capitalizations and closing prices of all stocks available from CRSP for each year. We define BE/ME ratios as the book value of common equity from Research Insight ${ }^{\mathbb{B}}$, divided by the year-end market value of common equity of the previous year. We delete firms with negative book to common equity ratios. The previous five years of stock returns are retrieved from CRSP. Earnings per share and CEO years of service at the time of selection as a Best CEO are retrieved from Research Insight. Our potential universe of matching firms consists of all remaining stocks that have available data from CRSP and Research Insight. If a company had previously been ranked on a best CEO list, it is excluded from the potential set of matching firms. In order to derive the best possible match for each firm in our Best CEO sample, we calculate the following matching score (MS) for each Best CEO stock against each of the remaining stocks:

$$
M S=\left[\frac{X_{1}^{B}-X_{1}^{M}}{\left(X_{1}^{B}+X_{1}^{M}\right) / 2}\right]^{2}+\left[\frac{X_{2}^{B}-X_{2}^{M}}{\left(X_{2}^{B}+X_{2}^{M}\right) / 2}\right]^{2}+\left[\frac{X_{3}^{B}-X_{3}^{M}}{\left(X_{3}^{B}+X_{3}^{M}\right) / 2}\right]^{2}
$$

where:

$\mathrm{X}_{1} \quad$ represents the first matching set of characteristics: market capitalization or the previous five years of EPS growth rate

$\mathrm{X}_{2}$ represents the second matching set of characteristics: the BE/ME ratio or the previous five years of annual stock returns 
$\mathrm{X}_{3}$ represents the third matching set of characteristics (for Barron Match 2 only): CEO years of service at the time of selection as a best CEO

B refers to the Best CEO sample

$\mathrm{M}$ refers to the remaining stock universe

Then, for each stock in the Best CEO sample, we select the stock with the smallest MS. We repeat the same procedure for each sample year in our study.

Our size and BE/ME match portfolios follow the method described in Barber and Lyon (1997). They argue that matching sample companies to control for size and BE/ME ratio will correct for the possible sources of misspecification and yield well-specified test statistics because it alleviates the new listing, rebalancing, and skewness biases. Following Loughran and Ritter (1995), we do not match the sample by market capitalization and industry for two reasons: first, our matching method will minimize possible industry misclassification; and second, suitable industry matches are not always possible due to the limited number of available companies within the industry that match up comparatively to sample companies.(Note 3)

In order to test whether newly-selected CEO winners or repeat winners have different announcement effects, we develop two sub-samples:

- New CEO sample: the CEO of the firm is selected as best CEO for the first time.

- Repeat winner sample: the CEO of the firm has been selected as best CEO in the previous year(s).

Table 2 shows the mean values of the characteristics of our CEO sample, the matched samples, and the sub-samples. The table shows that the Best CEO sample and the matched samples are very similar in their matching characteristics. Since not all best CEO stocks have available CEO compensation and service years data from Research Insight, only 101 matched pairs exist using our Barron Match 2 method. The results also show that our Barron's Match 1 and Match 2 portfolios are much smaller compared with CEO sample in terms of market capitalization. This may indicate that firm size may be a potential filtering rule for selecting the best CEO companies. Their CEOs are also paid less compared with CEO sample. So we need to be careful about the interpretation of results when compared with the Barron's Match 1 and Match 2 portfolios. The Size and BE/ME match portfolio has on average lower annual stock returns and EPS growth for the past 5 years compared with CEO sample. Among the two sub-samples of new CEO sample and repeat winner sample, the repeat winner sample has larger firm size and lower BE/ME ratios.

\section{(Insert Table 2 here)}

By constructing the matched sample based on size and book to market, we are implicitly controlling for the affect related factors that Statman et al. (2008) argue are measures of the subjective risk attributable to negative affect. By matching the comparison portfolios on these measures of affect, our null hypothesis is that there will be insignificant differences in the returns to the Barron's portfolio compared to the matched portfolio.

\section{Empirical Results}

\subsection{Announcement Effect}

To examine the short-term announcement effects, we use standard event methodology to generate abnormal returns pertaining to the announcements of being selected as a best CEO.

It is important to consider the possibility of a more gradual diffusion of the information contained in Barron's announcement. Our study is not unique in this regard. While examining the stock price response to news surrounding the development of drugs by EntreMed that may cure certain types of cancer, Huberman and Regev (2001) employ a 15-month "event window" in their analysis. In other types of studies (e.g., bond rating changes) the market reaction is studied over a wide range of announcement windows reflecting how the market may anticipate the ratings change before the formal announcement takes place (Goh and Ederington, 1993).

We report the share price response to the release of this survey beginning 5 days prior to the actual event "date."The market model is used to estimate expected returns. Parameter estimates are calculated for the period $(-326$, -71).Expected returns are estimated during the interval $(-5,5)$.Following Dodd and Warner (1983), and based on the earlier work of May (1971) and Patell (1976), standard event methodology is employed.

Table 3 shows the results of event study of our Best CEO sample and sub-samples. Panel A shows that there are no significant announcement effect on date 0 , but significantly negative abnormal returns (at 5 percent level) for Best CEO sample and repeat winner sub-sample. Over the event window $(-5,+5)$, all three samples have shown a significantly negative cumulative abnormal returns. The results indicate that the announcement of being selected as CEO receives a 
negative market reaction. As such, there no evidence to support our first hypothesis of anincrease in the positive affect of these firm as a result of the firms' mention of having a top CEO in contrast to the apparent short term increase found by Statman et al. in the case of the most admired firms.

\section{(Insert Table 3 here)}

Since the individual companies in the Best CEO sample will have the same press release date in each year, our test statistics may be biased due to a lack of independence (Note 4). To address this potential bias, we form event portfolios each year consisting of all companies announced on the same date and repeat the event study using these portfolios rather than the individual companies (Note 5). Results (reported in Table 3) of event portfolios show qualitatively similar abnormal returns across event windows. However, since most of the CARs for the event portfolio tests are not statistically significant, this finding suggests that the lack of independence may pose some problem for our results, and we need to interpret our event study results with caution.

Furthermore, since we have some foreign firms in our Best CEO sample, and we use their US data for calculation of returns, there might be problems of non-synchronous trading for these non-US firms. For example, Toyota is listed in Japan and the trading hours in Japan do not overlap with the trading hours in New York.

To examine whether our results are driven by some other factors such as stock volatility and trading volume surrounding the event windows, we retrieve the share volume and stock returns for our Best CEO sample surrounding the event window of $(-60,60)$. We then compare the share volume and stock return volatility between the $(-5,5)$ event window and the rest of the trading days. We do not find statistically significant difference (Note 6) between the event window and non-event window. This suggests that stock volatility or trading volume may not be the driving factors of the event study results.

\subsection{Post Announcement Long-term Stock Performance}

Beyond the lack of independence of announcement dates, non-synchronized trading, and possible information leakagenoted previously, another important reason for having some reservations about the robustness of the event study results is that Barron's is not as prominent a publication as the Wall Street Journal - the basis for most event studies. The same concern applies to the continued "announcements" made by the individual companies following the initial press release by Barron's. While the information becomes public at the time of the press release, dissemination of the news can be further confounded by readers of Barron receiving their copies of the periodical on different days due to differences in mailing times. For these reasons, the use of return measures involving longer holding periods may be more revealing.

We next compare annual holding period and risk-adjusted returns of the Best CEO firms to the performance of their matched samples and the S\&P 500 Index. The annual holding periods start with the Barron's announcement and continue through the next release date, at which point the next portfolio is constructed based on the subsequent year's list. A paired difference test is used to calculate a student $t$-test statistic with $n-1$ degrees of freedom to analyze raw returns statistically against each benchmark.

$$
\mathrm{t} \equiv \frac{\overline{\mathrm{d}}}{\mathrm{S}_{\mathrm{d}}} \mathrm{x} \sqrt{\mathrm{n}}
$$

where:

$-$

$\mathrm{d}=$ the mean difference between the market and portfolio return each day

$\mathrm{sd}=$ the standard deviation of the difference between the returns each daily

$\mathrm{n}=$ equals the number of days corresponding to the annual holding period.

While comparison of raw return data gives us some information concerning the performance of each of the portfolios, little information is gained with respect to the level of risk contained in the portfolios. Two commonly used risk-adjusted measures are calculated for comparison purposes.

First, we calculate the Sharpe $(1966,1994)$ Index measures for all portfolios. The Sharpe Index considers excess return per unit of total risk.

$$
\mathrm{S}=d / s_{d}
$$

where: 
$\mathrm{d}=$ mean daily difference between the Best CEO portfolio or matched portfolio stocks and the T-bill return, calculated over respective holding periods

$\mathrm{s}_{\mathrm{d}}=$ the sample standard deviation of the daily return differences

The standard deviation measures total risk, as opposed to systematic or market risk. Therefore, the Sharpe Index is the appropriate measurement of risk-adjusted return when the investor is not well diversified and is exposed to some level of company-specific risk.

Next, we calculate the Treynor (1965) Index measures. The Treynor Index uses systematic risk, measured by beta, instead of total risk in calculating risk-adjusted measures. Therefore, the Treynor Index is the appropriate measurement of risk-adjusted return when the investor is well diversified and is not exposed to company-specific risk.

$$
\mathrm{T}=d / \beta^{\sqrt{\mathrm{n}}}
$$

where:

$\mathrm{d}=$ mean daily difference between the return on the Best CEO portfolio or matched portfolio stocks and the T-bill return, calculated over respective holding periods

$\beta=$ portfolio beta

$\mathrm{n}=$ number of days in the respective holding periods

The Sharpe Index measures return per unit of total risk. If an investor is holding a poorly diversified portfolio, the Sharpe ranking is particularly relevant. If an investor is holding a diversified portfolio, Treynor's measure of return per unit of systematic risk is the more relevant measure of performance.

Jensen's (1968) Alpha, a measure of differential return, shows whether a portfolio exhibits above or below average risk-adjusted returns. We calculate Jensen's Alpha, $\alpha$, as the intercept term of the regression of the excess returns on the portfolio of the Best CEO firms (or matched samples) against the excess returns of the market:

$$
R_{p t}-R_{f t}=\alpha+\beta\left(R_{m t}-R_{f t}\right)+e_{p t},
$$

A positive (negative) Alpha is consistent with a portfolio of undervalued (overvalued) securities. Our null hypothesis is that there will be insignificant differences in the risk-adjusted measures to the Barron's portfolio compared to the matched portfolio

The results of raw returns and risk-adjusted measures for our different samples are reported in Table 4.The results of cumulative raw returns show that the Best CEO sample has lower annual returns compared with its matched samples. The differences are statistically significant when they are compared with Barron Match 2 portfolios. When compared with the S\&P 500 index, though the Best CEO sample has higher raw returns than S\&P 500, the differences are not statistically significant. We observe similar results with respect to Sharpe and Treynor measures: the Best CEO sample does not have higher Sharpe and Treynor measures compared with their matched portfolios. Likewise, the Jensen's alpha measures show that although the Best CEO sample has positive alphas, none of these alphas are statistically significant.

\section{(Insert Table 4 here)}

We also test the long-run performance of the Barron's sample using the Fama-French (1993) 3-factor and 4-factor models. The 3-factor model is applied by regressing the daily excess returns for regulated portfolios on a market factor, a size factor, and a book-to-market factor. The 4-factor model is constructed by integrating the Fama-French 3-factor model with an additional factor capturing the one-year momentum anomaly documented by Jegadeesh and Titman (1993).Specifically, the 3- and 4-factor models are defined respectively as:

$$
\begin{aligned}
& R_{p t}-R_{f t}=a_{i}+b\left(R_{m t}-R_{f f}\right)+s S M B_{t}+h H M L_{t}+e_{t} ; \\
& R_{p t}-R_{f t}=a_{i}+b\left(R_{m t}-R_{f t}\right)+s S M B_{t}+h H M L_{t}+m U M D_{t}+e_{t} ;
\end{aligned}
$$

where:

$$
\begin{aligned}
& R_{p t}=\text { the simple return on the Best CEO sample } \\
& R_{f t}=\text { the return on one-month T-bills } \\
& R_{m t}=\text { the return on a value-weighted market index }
\end{aligned}
$$




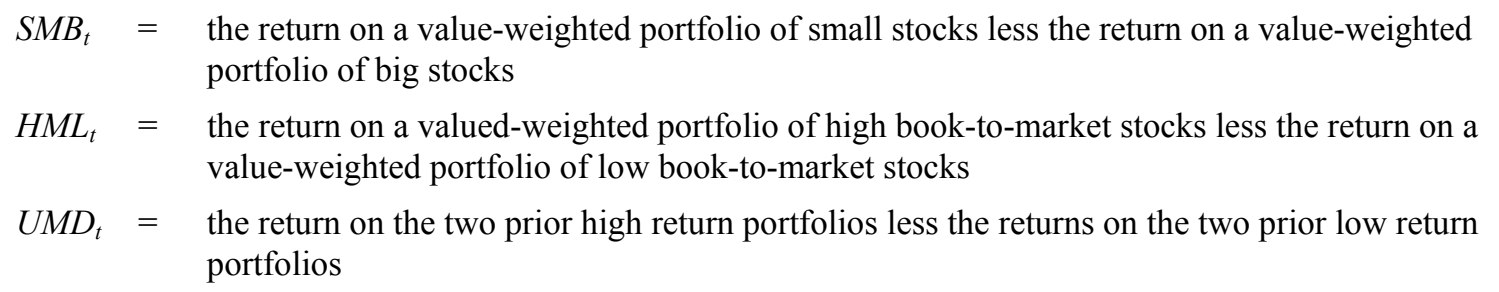

A positive intercept for these regressions, $a$, indicates that after controlling for the market, size, book-to-market ratio, and momentum factors in returns, the sample firms have performed better than expected. To determine whether the regression intercepts, $a$, are significantly different from zero, we employ the $t$-test statistics.

The results of Fama-French models are shown in Table 5.Our results indicate that after controlling for additional factors covered by the Fama-French models, we do not observe superior performance for our Best CEO sample and its sub-samples as none of the intercepts are statistically significant. For the 3 and 4 factor models, the coefficients for the market variable are positively significant, while in the 4-factor model, the book to market variable coefficient is negatively significant, which supports Statman, et. al's (2008) contention that the affect is reflected in the market size and book to market ratios.

\section{(Insert Table 5 here)}

Long-term performance is also assessed by using buy-and-hold abnormal returns (BHARs).Building on the work of Ritter (1991), Barber and Lyon (1997) find that BHARs can be used to address several issues regarding portfolio performance. A BHAR is the difference between the return on a buy-and-hold investment in a company of interest less the return on a buy-and-hold investment in a similar asset/portfolio. Barber and Lyon note that BHARs can overcome several biases inherent in estimating long-term CARs. Specifically, BHAR is calculated as:

$$
\mathrm{t}_{\text {BHAR }}={\overline{\mathrm{BHAR}_{\text {it }}}} /\left(\sigma\left(\mathrm{BHAR}_{\text {it }}\right) / \sqrt{\mathrm{n}}\right)
$$

where :

$$
\begin{aligned}
\overline{\mathrm{BHAR}}_{\mathrm{it}} & =\text { average buy-and-hold abnormal return } \\
\sigma\left(\mathrm{BHAR}_{\mathrm{it}}\right) & =\text { cross-sectional standard deviation of the buy-and-hold abnormal returns } \\
\mathrm{n} & =\text { the number of matched comparisons }
\end{aligned}
$$

For the calculation of BHAR, we use our matched samples as our benchmark portfolio. Therefore, in this study, BHAR is measured as the return of buy-and-hold investment of our Best CEO sample firm less the return of buy-and-hold investment of its matched firm, with differences cumulated over the portfolio. The BHAR holding periods start with the Barron's announcement and continue through the next release date.

We report the results of BHARs for our samples in Table 6. We test the null hypothesis that the buy-and-hold abnormal returns are equal to zero with the paired t-test.

In general, the t-test results show that our Best CEO firms do not outperform their matched samples using the annual buy-and-hold strategy. If we compare the Best CEO sample with Barron Match 2 portfolios, the Best CEO sample significantly (at the 1 percent level) underperforms its matched firms.

In sum, we fixed mixed evidence regarding our second hypothesis as to the superiority in holding period returns and risk-adjusted measures compared to appropriate benchmarks. In general, the longer-term cumulative raw returns show that the Best CEO sample has lower annual returns compared with its matched samples. The Best CEO sample did outperform the S \& P 500, but we are unable to distinguish performance of the Best CEO sample from its matched samples on a raw or risk-adjusted basis. This result is consistent with that of Agarwal et al. (2011) in their study of firms led by the CEOs of Britain's Most Admired Companies. In contrast, both Wade et al. (2006) who look at firms led by CEOs of the Year as determined by Financial World and. Malmendier, and Tate (2009) who examine "superstar" CEOs -those who are recipients of distinction such as being on Barron's list of Best CEOs -find the companies underperformed the matched samples in the years following any acclaim achieved by their CEOs.

\section{(Insert Table 6 here)}

\subsection{Post-Announcements Accounting Performance}

So far, our results indicate that Best CEO firms do not outperform their matched samples in the post-announcement period. However, a more complete understanding of long-run post-announcement performance may be gained from 
looking at accounting profitability or operating performance, since stock returns are forward looking so that any long-run effects may have been largely priced in at the time of announcement.

To investigate our third hypothesis, we use two measures of operating performance, return on asset (ROA) and earnings per share (EPS) growth rates for periods extending one and three years after the announcement, first in a trend analysis and then cross-sectionally to test our hypothesis. The results are reported in Table 7.

(Insert Table 7 here)

The results in Panel A show that the best CEO firms did not have higher profitability in the post-announcement periods. In fact, both the ROA and EPS growth rate decreased significantly three years after the announcement. To test whether the results are driven by general market conditions (e.g., the 2007-2008 financial crisis occurred during the middle of our sample period) rather than the announcement effect, we also show the results for our matched samples. In general, our Barron Match 1 and Match 2 portfolios experienced increases (with the exception of Barron Match 2 for the one year change) in ROAs, though the results are not statistically significant. T-tests of changes of ROAs and EPS growth rates between the Best CEO and their matched samples also indicate that there are no statistical differences between the accounting performance of Best CEO and their matched samples refuting our third hypothesis. This result contrasts with those of Wade et al. (2006) who find a deterioration in operating results for 'CEO of the Year' companies and Agarwal et al. (2011) who find continued superior operating performance in the Britain's Most Admired Companies. Malmendier, and Tate (2009) note that "superstar" CEOs are more likely to engage in earnings management compared to those who operate more anonymously.

\subsection{Do Best CEO Firms Perform Better During Extreme Market Conditions?}

Our results do not show any significant differences between the returns of the Best CEO sample and their matched samples. Next, we test our fourth hypothesis regarding the comparison of stock performance of the Best CEO sample and their matched samples during extreme market conditions. We investigate days during our sample period when the market rose or fell by some unusually large amount and then compare the well-led portfolio with their matched sample counterparts. We define "up days" as the days when S\&P 500 index rose by at least two percent compared to its previous day's index level, and "down days" as the days when S\&P 500 index fell by at least two percent compared to previous day. From this criterion, we identified 66 up days and 80 down days during our sample period. Then, for each up day or down day, we retrieve the daily returns for both the Best CEO sample and its matched samples within the period of ten, 20, and 30 days after the market upturns or downturns. Then we compare the mean daily returns and the volatility of daily returns (measured by standard deviation of daily returns) of the Best CEO sample and its matched samples. In order to compare the risk-adjusted returns, we also calculate the mean daily returns divided by standard deviation of daily returns to measure mean returns per unit of total risk.

The results are reported in Table 8 and show that the Best CEO sample does not have higher returns than its matched samples during both good times and bad times. The results in Table 8 show that after adjusting for risk, the Best CEO sample generally underperforms its matched samples during both good and bad times, especially when compared with Barron Match 1 and Match 2 portfolios. The results contrast with those of Filbeck, Gorman and Zhao (2010) who in their study the consequences of firms being named as a top company for leaders by Chief Executive magazine find that firms named in that survey had superior returns during times of higher volatility. However, similar to the results reported here, they find there were otherwise no differential long- or short-term returns for the top companies for leaders and other comparison portfolios. Thus, we find little support for our fourth hypothesis regarding superior performance being observed by firms whose CEOs are selected for inclusion in the World's Best CEOs during extreme market conditions.

(Insert Table 8 here)

\subsection{Post-Announcements CEO Compensations}

Our results so far indicate that the announcements related to the selection of the Best CEO sample do not lead to any significant effect (if not negative) regarding stock performance or accounting performance. Next, in order to test our fifth hypothesis, we retrieve CEO compensation data (including salary, bonus, and annual total compensation) from Research Insight. Our results are reported in Table 9. Our results show that for the Best CEO sample, although salaries increased significantly (at the 5 percent level) three years after the announcement, their total compensation decreased significantly (at the 1 percent level). When we compare the changes of CEO compensation to our matched samples, none of them (with the exception of size and BE/ME match for the one year post-announcement period) have significantly different changes regarding total compensation. T-tests of changes between the Best CEO compensation and matched samples indicate that the changes in CEO compensation are mostly driven by the stock performance of the firm, rather than whether the CEO is being selected as among the World's Best CEOs. In other words, contrary to our 
hypothesis, being recognized by Barron's as a superior CEO does not lead to significant changes in a CEO's personal benefits. This result contrasts with those of both Wade et al. (2006) and Malmendier, and Tate (2009) who find that compensation increases following certification as a top CEO.

\section{(Insert Table 9 here)}

\section{Conclusions}

In this study, we investigate whether a company's stock price performance is influenced by its CEO being named to Barron's World's Best CEO list, based on an initial announcement effect and on a longer-term, risk-adjusted basis. The results indicate that the announcement of being selected among the best CEOs actually results in a negative market reaction. While not statistically significant, the Best CEO sample did outperform the S \& $\mathrm{P} 500$.However, the longer-term cumulative raw returns show that the Best CEO sample has lower annual returns compared with its matched samples. On a risk-adjusted basis, we are unable to distinguish performance of the Best CEO sample from its matched samples. While the Best CEO sample generates positive Jensen's alpha values, the values are also not statistically significant. We also employ the Fama-French model as well as BHARs and find similar results.

In addition, the Best CEO sample did not have higher profitability in the post-announcement periods. In fact, both the ROA and EPS growth rate decreased significantly three years after the announcement. For the CEOs themselves, it appears that any changes in compensation are mostly driven by the stock performance of the firm, rather than whether the CEO is being selected as a best CEO in the world. In this regard, to the extent that inclusion of the companies in the Barron's survey leads to an increase in the positive affect of the firms, our results do not support the hypotheses of Statman et al. (2008).

While the recent works of Fang and Peress (2009) and others show how the media can influence corporate returns, in the case of the publication of Barron's survey of the top CEOS, we do not find evidence consistent with media influence. Whether this is due to a lack of information content in listing of the Best CEOs or whether the lack of market reaction can be attributed to the medium rather than the message is an unresolved issue. More research is required to better identify the aspects of management quality that are most closely associated with financial performance and to determine the most effective ways for conveying this information to the market.

\section{References}

Adams, R., H. Almeida, and D. Ferreira. (2005). Powerful CEOs and their impact on corporate performance. The Review of Financial Studies. 18 (4). 1403- 1432. http://dx.doi.org/10.1093/rfs/hhi030

Anderson, J. and G. Smith. (2006). A great company can be a great investment. Financial Analysts Journal. 62 (4), 86-91. http://dx.doi.org/10.2469/faj.v62.n4.4189

Agarwal,V., R Taffler and M Brown, (2011). Is management quality value relevant?. Journal of Business Finance \& Accounting. 38(9 \& 10) , 1184-1208. http://dx.doi: 10.1111/j.1468-5957.2011.02267.x

Barber, B. and J. Lyon. (1997). Detecting long-run abnormal stock returns: The empirical power and specification of test statistics. Journal of Financial Economics. 43 (3), 341-372. http://dx.doi.org/10.1016/S0304-405X(96)00890-2

Brown, S.J., and J.B. Warner. (1980). Measuring security price performance. Journal of Financial Economics. 8 (3), 205-258. http://dx.doi.org/10.1016/0304-405X(80)90002-1

Brown, S.J., and J.B. Warner. (1985). Using daily stock returns: The case of event studies. Journal of Financial Economics. 14 (1), 3-31. http://dx.doi.org/10.1016/0304-405X(85)90042-X

Demaree, A. (1993). What's behind a reputation. Fortune. 127 (3), 196.

Canella, A. and D. Hambrick. (1993). Effects of executive departures on the performance of acquired firms. Strategic Management Journal. 14 (S1), 137-152. http://dx.doi.org/10.1002/smj.4250140911

Chang, Y., S. Dasgupta, and G. Hilary. (2010). CEO ability, pay, and firm performance. Management Science. 56 (10), 1633-1652. http://dx.doi.org/10.1287/mnsc.1100.1205

Clarke, R. and M. Statman. (1994). Growth, value, good, and bad. Financial Analysts Journal, 50 (6), 82-86. http://dx.doi.org/10.2469/faj.v50.n6.82

Collins, J. (2001). Good to great. HarperCollins Publishers: New York.

Covert, J. and T. Sattersten. (2009). The 100 best business books of all time: What they say, why they matter, and how they can help you. Penguin Group, New York. 
Dodd, P. and J. Warner. (1983). On corporate governance. Journal of Financial Economics. 11 (1-4), 401-438. http://dx.doi.org/10.1016/0304-405X(83)90018-1

Fama, E., and French, F. (1993). Common risk factors in the returns on stocks and bonds. Journal of Financial Economics. 33 (1), 3-56. http://dx.doi.org/10.1016/0304-405X(93)90023-5

Fang, L. and J. Peress. (2009). Media coverage and the cross-section of stock returns. The Journal of Finance. 64 (5), 2023-2052. http://dx.doi.org/10.1111/j.1540-6261.2009.01493.x

Fee, C. (2003). Raids, rewards, and reputations in the market for managerial talent. The Review of Financial Studies. 16 (4), 1315-1357. http://dx.doi.org/10.1093/rfs/hhg031

Filbeck, G., R. Gorman, and D. Preece. (1997). Fortune's most admired firms: An investor's perspective. Studies in Economics and Finance. 18 (1), 74-93.

Filbeck, G. and R. Gorman, X. Zhao. (2010). Good to great: What's so good about being great? Financial Decisions. 22 (2), $1-15$.

Filbeck, G., R. Gorman, and X. Zhao. (2010). Identifying the best companies for leaders: does it lead to higher returns? Managerial and Decision Economics. 31 (1), 19-31

Filbeck, G., R. Gorman, and X. Zhao (2009). The Best Corporate Citizens: Are they good for their shareholders? Financial Review. 44 (2), 239-262. http://dx.doi.org/10.1111/j.1540-6288.2009.00217.x

Goh, J. and L. Ederington. (1993). "Is a bond downgrade bad news, good news, or no news for stockholders. Journal of Finance. 48 (5), 2001-2008. http://dx.doi.org/10.2307/2329078

Hammond, S. and J. Slocum, Jr. (1996). The impact of prior firm financial performance on subsequent corporate reputation. Journal of Business Ethics. 15 (2), 159-165. http://dx.doi.org/10.1007/BF00705584

Huberman, G. and T. Regev. (2001). Contagious speculation and a cure for cancer: A nonevent that made stock prices soar. Journal of Finance. 56 (1), 387-396. http://dx.doi.org/10.1111/0022-1082.00330

Jegadeesh, S. and S. Titman. (1993). Returns on buying winners and selling losers: Implications for stock market efficiency, Journal of Finance. 48 (1), 65-91. http://dx.doi.org/10.2307/2328882

Jennings, M. (2005). Ethics and investment management: true reform. Financial Analysts Journal. 61 (3), 45-58. http://dx.doi.org/10.2469/faj.v61.n3.2727

Jensen, M. (1968). The performance of mutual funds in the period 1945-1964. Journal of Finance. 23 (2), 389-416. http://dx.doi.org/10.2307/2325404

Loughran, T. and J. R. Ritter, (1995). The new issues puzzle, Journal of Finance, 50 (1), 23-51. http://dx.doi.org/10.2307/2329238

Malmendier, U. and G. Tate(2009). 'Superstar CEOs', Quarterly Journal of Economics, 124, 1593-638. http://www.jstor.org/stable/40506267

May, R. (1971). The influence of quarterly earnings announcements on investor decisions as reflected in common stock price changes. Empirical Research in Accounting: Selected Studies Supplement to Vol. 9, Journal of Accounting Research.

Meulbroek, L. (2001). The efficiency of equity-linked compensation: Understanding the full cost of awarding executive stock options, Financial Management. 30 (2), 5-30. http://dx.doi.org/10.2307/3666404

Patell, J. (1976). Corporate forecasts of earnings per share and stock price behavior: Empirical tests. Journal of Accounting Research. 14 (2), 246-276. http://dx.doi.org/10.2307/2490543

Sarkar, S., and F. Almudhaf. (2009). Forbes platinum 400 lists for the best big companies: Are they good investments. Working Paper: University of Texas at Arlington.

Savor, P., and Q. Lu. (2009). Do stock mergers create value for acquirers? Journal of Finance. 64 (3), 1061-1097. http://dx.doi.org/10.1111/j.1540-6261.2009.01459.x

Sharpe, W. (1966). Mutual fund performance. Journal of Business, 39 (1), 119-138. http://dx.doi.org/10.1086/294846

Sharpe, W. (1994). The Sharpe ratio, 1994. Journal of Portfolio Management. 21 (1), 4958. http://dx.doi.org/10.3905/jpm.1994.409501

Shea, C. (1999). The effect of leadership style on performance improvement on a manufacturing task, The Journal of Business. 72 (3), 407-422. http://dx.doi.org/10.1086/209620 
Shefrin, H. and M. Statman. (1993). A behavioral framework for expectations about stock returns." Working Paper, Santa Clara University.

Shefrin, H. and M. Statman. (1995). Making sense of beta, size and book-to-market: Investor expectations are consistent - but wrong. The Journal of Portfolio Management. 21 (2), 26-34. http://dx.doi.org/10.3905/jpm.1995.409506

Statman, M., K. Fisher, and D. Anginer. (2008). Affect in behavioral asset-pricing model. Financial Analysts Journal. 64 (2), 20-29. http://dx.doi.org/10.2469/faj.v64.n2.8

Treynor, J. (1965). How to rate management of investment funds. Harvard Business Review. 43 (1), 63-75.

Vergin, R. and M. Qoronfleh. (1998). Corporate reputation and the stock market. Business Horizons. 41 (1), 19-26. http://dx.doi.org/10.1016/S0007-6813(98)90060-X

Wade, J., J. Porac, T. Pollock and S. Graffin. (2006). The burden of celebrity: The impact of CEO certification contests on CEO pay and performance. Academy of Management Journal, 49, 643-80. http://www.jstor.org/stable/20159790

Ware, J. B. Michaels, and D. Primer. (2004). Investment leadership: Building a winning culture for long-term success. John Wiley \& Sons, Inc: New York.

Zingales, L. (2000). In search of new foundations. Journal of Finance. 55 (4), 1623-1654. http://dx.doi.org/10.1111/0022-1082.00262

Note 1. The annual surveys subsequently appeared in the March 27, 2006, March 26, 2007, March 24, 2008, March 23, 2009, and March 29, 2010 issues.

Note 2. We include foreign firms in our study sample as long as they have available data from CRSP and Research Insight. A total of 36 of our 138 announcements are from foreign firms. We use their US return and accounting data for calculation purposes.

Note 3. Savor and Lu (2009) use a modified version of the matching firm approach advocated by Barber and Lyon (1997). They first identify all firms with the same two-digit SIC code and market value of equity within 50 percent and 150 percent range of a given sample firm. They then select the firm with the closest BE/ME ratio of the sample firm and repeat the procedure ten times to obtain ten control firms. Thus, instead of selecting only one matching firm for each sample firm, they use a portfolio of 10 firms. Their main reason for this process is that matching just one firm is very sensitive to possible mismatches. We also explored the Savor and Lu method and obtained inferior matching results. The main reason is that the available stocks after the initial filtering are very limited and the matching properties on market value of equity and BE/ME ratio resulted in wider deviations from our matching criteria For example, by using their method, our sample has a BE/ME ratio of 1.99 while the corresponding figure for the matched sample is 0.58 . We also considered another filtering rule (BE/ME ratio of the available stocks should be within 50 percent to 150 percent of that of the sample firm) for the matching, but about $40 \%$ of the sample stocks cannot find the matching stocks by this method.

Note 4. We thank an anonymous referee for this comment

Note 5. Please see Brown and Warner (1980, 1985), and Filbeck, Gorman and Zhao (2009) for reference to this method.

Note 6. Results omitted for brevity. 
Table 1. World's Best CEOs

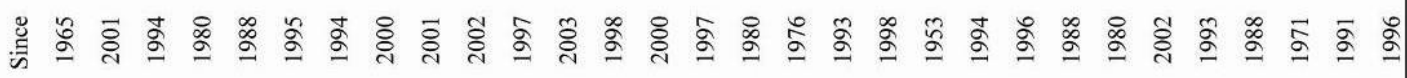

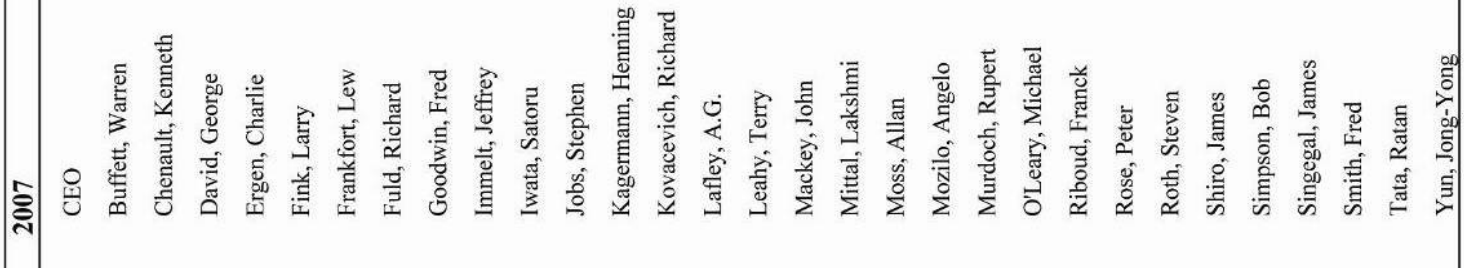

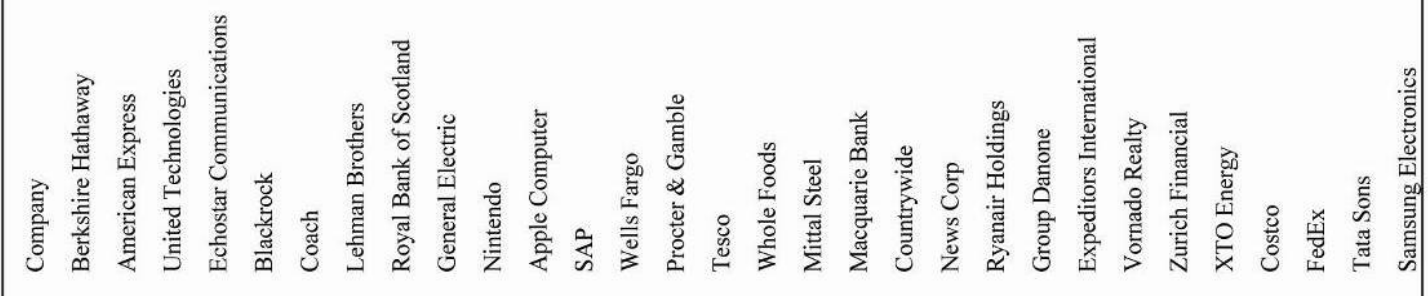

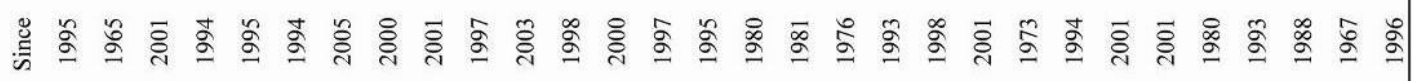

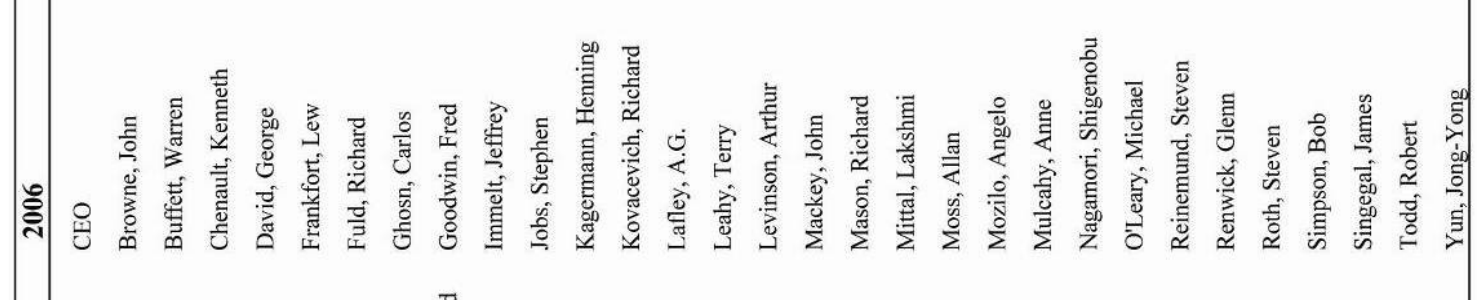

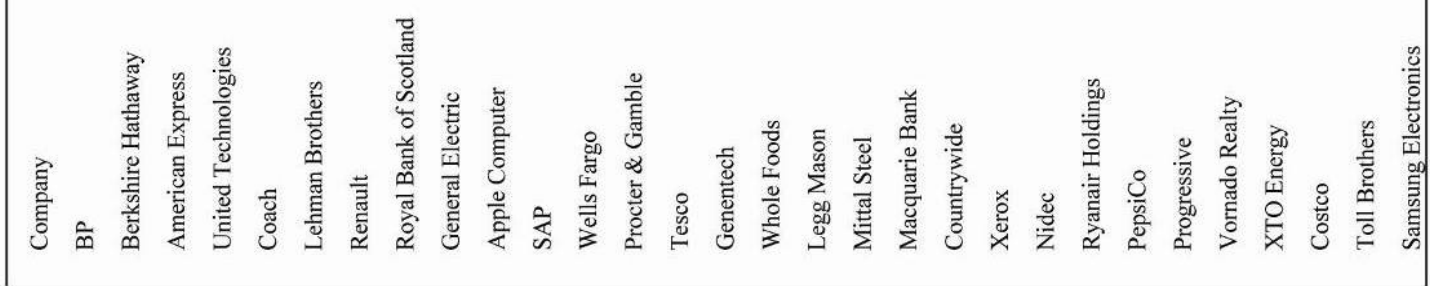

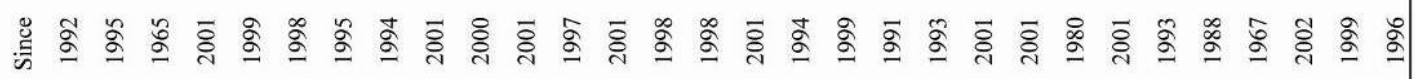

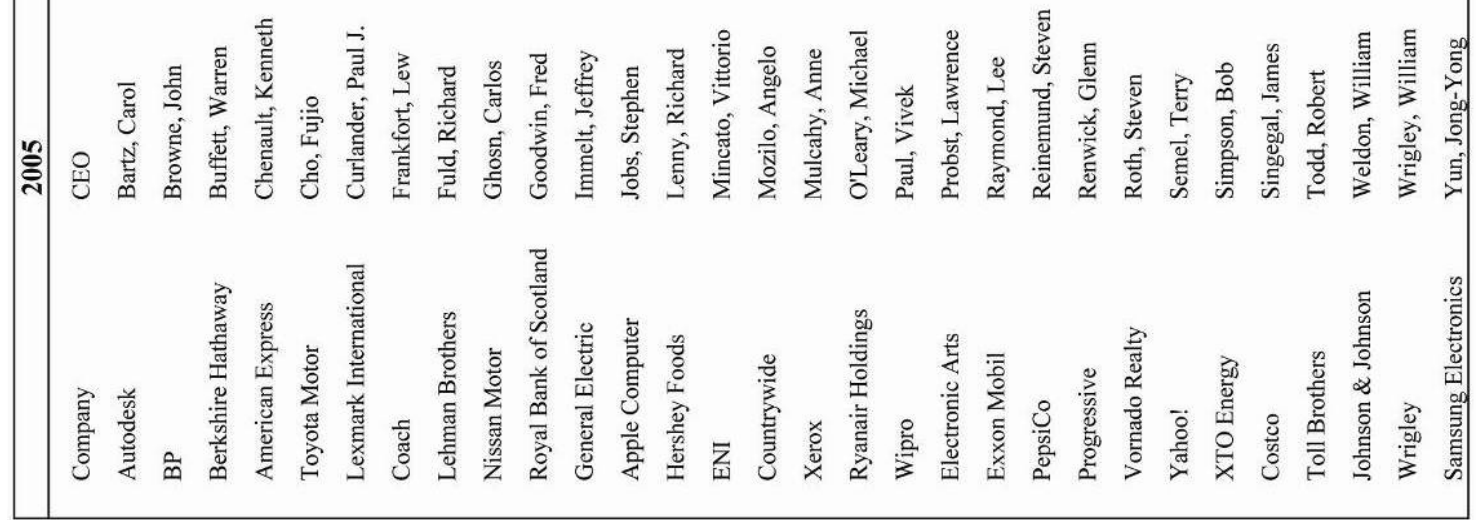




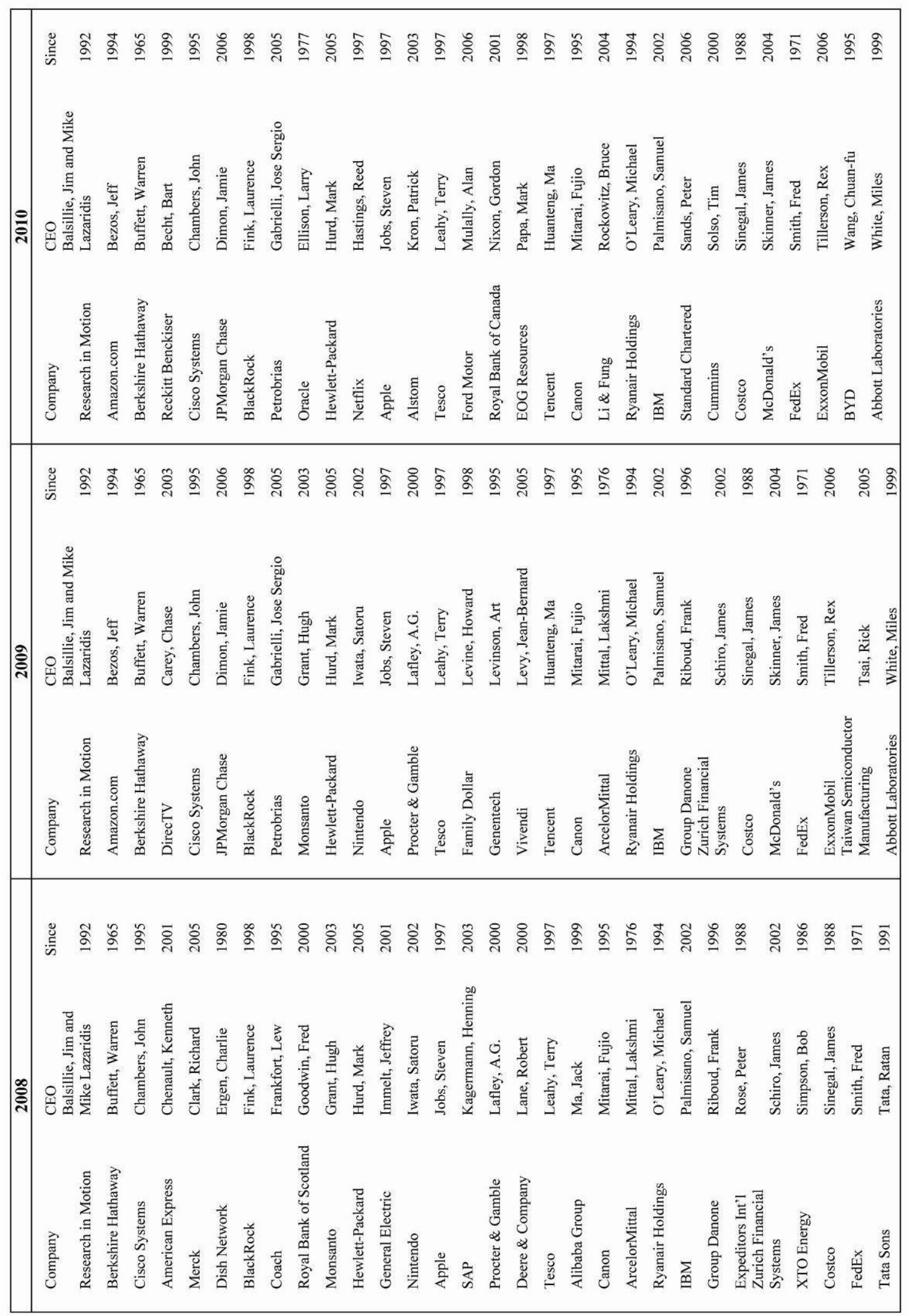


Table 2. Descriptive statistics for Best CEO Sample, matched samples and sub-samples

\begin{tabular}{|c|c|c|c|c|c|c|}
\hline Measure & $\begin{array}{l}\text { Best CEO } \\
\text { Sample }\end{array}$ & $\begin{array}{l}\text { Size and } \\
\text { BE/ME } \\
\text { Match }\end{array}$ & $\begin{array}{l}\text { Barron } \\
\text { Match } 1\end{array}$ & $\begin{array}{l}\text { Barron } \\
\text { Match } 2 \\
\end{array}$ & $\begin{array}{l}\text { New CEO } \\
\text { Sample }\end{array}$ & $\begin{array}{l}\text { Repeat } \\
\text { Winner } \\
\text { Sample } \\
\end{array}$ \\
\hline Number of events & 138 & 138 & 138 & 101 & 62 & 76 \\
\hline Market capitalization ( $\$$ millions) & 64,334 & 62,701 & 3,282 & 9,295 & 52,919 & 73,646 \\
\hline $\mathrm{BE} / \mathrm{ME}$ ratio & 1.74 & 1.62 & 2.77 & 0.41 & 2.63 & 1.00 \\
\hline Past 5 years average annual stock returns & 0.233 & 0.146 & 0.233 & 0.223 & 0.232 & 0.234 \\
\hline Past 5 years average EPS growth rate & 0.387 & -0.073 & 0.397 & 0.275 & 0.285 & 0.469 \\
\hline Service years when being selected as best CEOs & 11 & 6 & 7 & 11 & 11 & 12 \\
\hline Salaries ( $\$$ thousands) when being selected as best CEOs & 1,143 & 1,106 & 766 & 733 & 1,187 & 1,106 \\
\hline
\end{tabular}

Table 2 reports the mean values of the characteristics for our Best CEO sample, its matched samples and sub-samples. We retrieve previous year-end market capitalization and closing price of all stocks available from CRSP for each year. We define BE/ME ratios as the book value of common equity from Research Insight ${ }^{\circledR}$, divided by the year-end market value of common equity of the previous year. We delete firms with negative book to common equity ratios. Past 5 years stock returns are retrieved from CRSP. Earnings per share and CEO service years when selected as best CEO are retrieved from Research Insight. We construct three matched portfolios as our benchmark: size and BE/ME match (matched based on the previous year end's market capitalization and book-tomarket ratio), Barron match 1 (matched based on average EPS growth rate and annual stock returns for the previous five years) and Barron match 2 (matched based on average EPS growth rate and annual stock returns for the previous five years, and years of service at the time of the CEO is selected as a Best CEO). We also construct two sub-samples: the new CEO sample and the repeat winner sample, to test whether newly selected CEOs (or repeatedly selected CEOs) will affect stock performance.

Table 3. Abnormal returns (ARs) and cumulative abnormal returns (CARs) around the event date for Best CEO sample

\begin{tabular}{|c|c|c|c|c|c|c|c|c|}
\hline & \multicolumn{2}{|c|}{$\begin{array}{l}\text { Best CEO Sample } \\
\quad(\mathrm{n}=138)\end{array}$} & \multicolumn{2}{|c|}{$\begin{array}{c}\text { New CEO Sample } \\
(\mathrm{n}=62)\end{array}$} & \multicolumn{2}{|c|}{$\begin{array}{l}\text { Repeat Winner } \\
\text { Sample }(n=76)\end{array}$} & \multicolumn{2}{|c|}{ Event Portfolios } \\
\hline \multicolumn{9}{|c|}{ Panel A. Abnormal returns ( $\%$ ) around event date } \\
\hline Day & $\mathrm{AR}$ & Z-stat & $\mathrm{AR}$ & Z-stat & AR & Z-stat & AR & Z-stat \\
\hline-5 & -0.03 & 0.86 & 0.11 & 1.17 & -0.15 & 0.10 & 0.01 & 0.07 \\
\hline-4 & -0.06 & 0.08 & -0.02 & -0.11 & -0.09 & 0.20 & -0.14 & -1.06 \\
\hline-3 & -0.41 & $-1.94 * *$ & -0.66 & $-3.36 * * *$ & -0.21 & 0.46 & -0.27 & -1.95 \\
\hline-2 & -0.52 & $-3.86 * * *$ & -0.69 & $-2.90 * * *$ & -0.37 & $-2.58 * * *$ & -0.15 & -1.14 \\
\hline-1 & -0.12 & -0.90 & -0.46 & $-2.42 * * *$ & 0.16 & 0.99 & 0.01 & 0.11 \\
\hline 0 & 0.12 & 0.16 & 0.38 & 1.04 & -0.09 & -0.73 & 0.17 & 0.72 \\
\hline 1 & -0.18 & $-1.70^{*}$ & -0.26 & -0.95 & -0.11 & $-1.43 *$ & 0.01 & 0.02 \\
\hline 2 & -0.23 & -1.12 & -0.12 & -0.15 & -0.33 & $-1.38^{*}$ & 0.01 & 0.06 \\
\hline 3 & -0.52 & $-2.75 * * *$ & -0.48 & $-1.95 * *$ & -0.55 & $-1.95 * *$ & -0.19 & -1.07 \\
\hline 4 & 0.02 & -0.10 & 0.22 & 0.38 & -0.16 & -0.49 & 0.20 & 1.02 \\
\hline 5 & 0.07 & 0.19 & 0.04 & 0.32 & 0.10 & -0.04 & -0.05 & -0.22 \\
\hline
\end{tabular}

Panel B. Cumulative abnormal returns (\%) around event date

\begin{tabular}{cllllllll}
\hline Interval & CAR & Z-stat & CAR & Z-stat & CAR & Z-stat & CAR & Z-stat \\
\hline$(-5,-2)$ & -1.02 & $-2.43^{* * *}$ & -1.26 & $-2.60^{* * *}$ & -0.83 & -0.91 & -0.55 & $-2.52^{*}$ \\
$(-1,0)$ & 0.00 & -0.52 & -0.97 & -0.97 & 0.07 & 0.19 & 0.18 & 0.85 \\
$(1,5)$ & -0.84 & $-2.46^{* * *}$ & -0.60 & -1.05 & -1.05 & $-2.37^{* * *}$ & -0.02 & -0.06 \\
$(-5,5)$ & -1.86 & $-3.34 * * *$ & -1.93 & $-2.69 * * *$ & -1.80 & $-2.07 * *$ & -0.39 & -0.63 \\
\hline
\end{tabular}

Table 3 reports the results of the event study for the Best CEO sample.Panel A shows the abnormal returns (in percentage) around event date, and Panel B shows the cumulative abnormal returns (in percentage). We test the share price response to the release of this survey beginning 5 days prior to the event date by calculating abnormal returns (ARs) and cumulative abnormal returns (CARs).Expected returns are estimated from the market model.Expected returns are estimated from the market model.Expected returns are estimated during the interval $(-5,5)$ and estimates of the parameters are calculated for the trading day period $(-301,-46)$ using 255 trading day year.We follow Dodd and Warner's $(1983)$ event-study method.

$* * *, * *, *$ indicate statistical significance at $0.01,0.05$ and 0.10 level, respectively. 
Table 4. Raw and risk-adjusted returns of the Best CEO sample compared to the S\&P 500 and the matched samples

\begin{tabular}{|c|c|c|c|}
\hline & Best CEO Sample & New CEO Sample & $\begin{array}{l}\text { Repeat Winner } \\
\text { Sample }\end{array}$ \\
\hline \multicolumn{4}{|l|}{ Panel A. Cumulative raw return (\%) } \\
\hline Best CEO Sample (1) & 8.588 & 11.117 & 6.525 \\
\hline Size and BE/ME Match (2) & 8.529 & 13.836 & 4.270 \\
\hline CAR: (1) - (2) & 0.059 & -2.719 & 2.255 \\
\hline Barron Match 1 (3) & 12.082 & 18.953 & 6.510 \\
\hline CAR: (1) - (3) & -3.494 & -7.836 & 0.015 \\
\hline Barron Match 2 (4) & 17.902 & 23.467 & 13.643 \\
\hline CAR: (1) - (4) & $-11.094 * * *$ & $-12.843^{* *}$ & $-9.630^{*}$ \\
\hline S\&P 500 Index(5) & 4.254 & 5.839 & 2.961 \\
\hline CAR: (1) - (5) & $4.334 *$ & $5.278^{*}$ & 3.564 \\
\hline \multicolumn{4}{|c|}{ Panel B. Risk-adjusted performance measures } \\
\hline \multicolumn{4}{|c|}{ Sharpe measure } \\
\hline Best CEO Sample & 0.0148 & 0.0210 & 0.0092 \\
\hline Size and BE/ME Match & 0.0157 & 0.0231 & 0.0054 \\
\hline Barron Match 1 & 0.0238 & 0.0334 & 0.0074 \\
\hline Barron Match 2 & 0.0363 & 0.0378 & 0.0258 \\
\hline S\&P 500 Index & 0.0045 & 0.0045 & 0.0010 \\
\hline \multicolumn{4}{|l|}{ Treynor measure } \\
\hline Best CEO Sample & 0.0230 & 0.0353 & 0.0156 \\
\hline Size and BE/ME Match & 0.0243 & 0.0392 & 0.0091 \\
\hline Barron Match 1 & 0.0439 & 0.0748 & 0.0152 \\
\hline Barron Match 2 & 0.0606 & 0.0685 & 0.0472 \\
\hline S\&P 500 Index & 0.0067 & 0.0067 & 0.0016 \\
\hline \multicolumn{4}{|l|}{ Jensen's alpha } \\
\hline Best CEO Sample & 0.0175 & 0.0281 & 0.0156 \\
\hline
\end{tabular}

Table 4 reports the raw and risk-adjusted returns of the Best CEO sample compared to S\&P 500 and matched samples.Panel A reports the annualized raw returns for the Best CEO sample and benchmark portfolios (i.e., S\&P 500 returns and matched samples returns).For each stock in the Best CEO sample, we calculate its CAR compared to benchmark portfolio over the holding period and use the paired T-test to test whether CAR is significantly different from zero.Panel B calculates the three risk-adjusted performance measures: Sharpe ratio, Treynor ratio and Jensen's alpha.

$* * *, * *, *$ indicate statistical significance at $0.01,0.05$ and 0.10 level, respectively. 
Table 5. Regression results for Fama-French 3- and 4-factor model for the Best CEO sample

$\begin{array}{lll}\begin{array}{l}\text { Best CEO Sample } \\ (\mathrm{n}=138)\end{array} & \begin{array}{l}\text { New CEO Sample } \\ (\mathrm{n}=62)\end{array} & \begin{array}{l}\text { Repeat Winner } \\ \text { Sample }(\mathrm{n}=76)\end{array}\end{array}$

\begin{tabular}{lllll}
\hline Panel A. $\mathrm{R}_{\mathrm{it} t}-R_{f t}=a_{i}+b\left(R_{m t}-R_{f t}\right)+s S M B_{t}+h H M L_{t}+e_{i t} ;$ \\
\multirow{3}{*}{ Intercept } & Coefficient & 0.0119 & 0.0125 & \\
& t-stat & 1.37 & 1.02 & 0.0114 \\
\multirow{2}{*}{$\mathrm{R}_{\mathrm{mt}}-\mathrm{R}_{\mathrm{ft}}$} & Coefficient & 1.1130 & 1.0885 & 0.92 \\
& t-stat & $29.82^{* * *}$ & $21.91^{* * *}$ & 1.1329 \\
$\mathrm{SMB}_{\mathrm{t}}$ & Coefficient & -0.0204 & -0.0514 & $20.79^{* * *}$ \\
& t-stat & -0.61 & -1.07 & 0.0049 \\
$\mathrm{HML}_{\mathrm{t}}$ & Coefficient & -0.0571 & -0.0743 & 0.11 \\
& t-stat & -0.71 & -0.58 & -0.0431
\end{tabular}

Panel B. $\mathrm{R}_{i t}-R_{f t}=a_{i}+b\left(R_{m t}-R_{f t}\right)+s S M B_{t}+h H M L_{t}+m U M D_{t}+e_{i t}$;

$\begin{array}{cllll}\text { Intercept } & \text { Coefficient } & 0.0111 & 0.0136 & 0.0090 \\ & \mathrm{t} \text {-statistics } & 1.25 & 1.06 & 0.74 \\ \mathrm{R}_{\mathrm{mt}}-\mathrm{R}_{\mathrm{ft}} & \text { Coefficient } & 1.0785 & 1.0293 & 1.1187 \\ & \mathrm{t} \text {-stat } & 31.33^{* * *} & 23.57^{* * *} & 21.86^{* * *} \\ \mathrm{SMB}_{\mathrm{t}} & \text { Coefficient } & -0.0645 & -0.1116 & -0.0261 \\ & \mathrm{t}-\text { stat } & -2.05^{* *} & -2.51^{* *} & -0.59 \\ \mathrm{HML}_{\mathrm{t}} & \text { Coefficient } & -0.1693 & -0.2139 & -0.1329 \\ & \mathrm{t} \text {-stat } & -2.80^{* * *} & -2.16^{* *} & -1.78^{*} \\ \mathrm{UMD}_{\mathrm{t}} & \text { Coefficient } & 0.0076 & 0.1799 & -0.1330 \\ & \mathrm{t} \text {-stat } & 0.13 & 1.84^{*} & -2.08^{* *}\end{array}$

Table 5 shows the regression results of Fama-French 3- and 4-factor models for the Best CEO sample. The 3-factor model is applied by regressing the post-event daily excess returns for asset $i$ on a market factor, a size factor, and a book-to-market factor.The 4-factor model is constructed by integrating the Fama-French (1993) 3-factor model with an additional factor capturing the one-year momentum anomaly reported by Jegadeesh and Titman (1993). We report their average regression coefficients from stock-by-stock regressions.To determine whether the regression coefficient is significantly different from zero, we calculate the $t$-statistic.The $t$-statistic is obtained by dividing the average coefficient by the cross-sectional standard deviation of the coefficient.

$* * *, * *, *$ indicate statistical significance at $0.01,0.05$ and 0.10 level, respectively. 
Table 6. Buy-and-hold abnormal returns (BHARs) for the Best CEO sample

\begin{tabular}{lllll}
\hline Sample & $\prod\left(1+R_{i t}\right)$ & $\prod\left(1+E\left(R_{i t}\right)\right)$ & BHAR & T-test \\
$\begin{array}{l}\text { Panel A. Buy and hold abnormal returns (BHARs) } \\
\text { match }\end{array}$ & & & & \\
\hline & & & & \\
Best CEO Sample (n=138) & 1.086 & 1.081 & 0.005 & 0.15 \\
New CEO Sample $(\mathrm{n}=62)$ & 1.105 & 1.144 & -0.039 & -0.77 \\
Repeat Winner Sample $(\mathrm{n}=76)$ & 1.072 & 1.032 & 0.040 & 0.91
\end{tabular}

Panel B. Buy and hold abnormal returns (BHARs) compared with Barron Match 1

$\begin{array}{lllll}\text { Best CEO Sample }(\mathrm{n}=138) & 1.086 & 1.111 & -0.025 & -0.44 \\ \text { New CEO Sample }(\mathrm{n}=62) & 1.105 & 1.182 & -0.077 & -0.94 \\ \text { Repeat Winner Sample }(\mathrm{n}=76) & 1.072 & 1.054 & 0.018 & 0.40\end{array}$

Panel C. Buy and hold abnormal returns (BHARs) compared with Barron Match 2

$\begin{array}{lllll}\text { Best CEO Sample }(\mathrm{n}=101) & 1.082 & 1.191 & -0.109 & -2.08^{* * *} \\ \text { New CEO Sample }(\mathrm{n}=46) & 1.105 & 1.261 & -0.156 & -2.44 * * \\ \text { Repeat Winner Sample }(\mathrm{n}=55) & 1.062 & 1.132 & -0.070 & -1.48\end{array}$

Table 6 reports the BHARs for the Best CEO sample.Panel A reports the results of the Best CEO sample compared with size and BE/ME match, while Panel B (C) reports the results of the Best CEO sample compared with Barron match 1 (Barron match 2) portfolio. We test the null hypothesis that the BHARs are equal to zero with t-test statistic.

$* * * * *, *$ indicate statistical significance at $0.01,0.05$ and 0.10 level, respectively.

Table 7. Changes of accounting performance one-year or three years after the announcement

\begin{tabular}{|c|c|c|c|c|c|c|c|c|}
\hline Sample & $\begin{array}{l}1 \text { year } \\
\text { before }(1)\end{array}$ & $\begin{array}{l}1 \text { year after } \\
\text { (2) }\end{array}$ & $\begin{array}{l}\text { Change } \\
(2)-(1)\end{array}$ & T-test & $\begin{array}{l}3 \text { years } \\
\text { before }(3)\end{array}$ & $\begin{array}{l}3 \text { years after } \\
\text { (4) }\end{array}$ & $\begin{array}{l}\text { Change } \\
(4)-(3)\end{array}$ & T-test \\
\hline \multicolumn{9}{|c|}{ Panel A. Change of ROA (\%) after the announcement } \\
\hline Whole Sample (1) & 13.44 & 13.12 & -0.92 & $-1.79 *$ & 13.29 & 12.21 & -1.38 & $-2.31 * *$ \\
\hline Size and BE/ME Match (2) & 12.90 & 10.86 & -1.92 & $-3.02 * * *$ & 12.64 & 10.41 & -1.91 & $-3.19 * * *$ \\
\hline$(1)-(2)$ & 0.55 & 2.26 & 0.99 & & 0.65 & 1.80 & 0.54 & \\
\hline Barron Match 1 (3) & 21.01 & 56.97 & 27.66 & 0.87 & 15.74 & 86.74 & 65.93 & 0.95 \\
\hline$(1)-(3)$ & -7.56 & -43.85 & -28.58 & & -2.45 & -74.52 & -67.30 & \\
\hline Barron Match 2 (4) & 12.17 & 12.16 & -0.34 & -0.42 & 11.58 & 11.78 & 0.44 & 0.53 \\
\hline$(1)-(4)$ & 1.27 & 0.96 & -0.59 & & 1.71 & 0.43 & -1.81 & \\
\hline New CEO Sample & 13.42 & 14.28 & 0.56 & 0.82 & 13.04 & 12.79 & -0.42 & -0.47 \\
\hline Repeat Winner Sample & 13.46 & 11.84 & -2.38 & $-3.27 * * *$ & 13.50 & 11.53 & -2.32 & $-2.96 * * *$ \\
\hline \multicolumn{9}{|c|}{ Panel B. Change of EPS growth rate (\%) after the announcement } \\
\hline Whole Sample (1) & 15.49 & 27.06 & 15.13 & 0.63 & 38.51 & 25.24 & -16.68 & -0.62 \\
\hline Size and BE/ME Match (2) & 10.61 & -21.50 & -23.52 & -0.91 & 16.41 & -23.39 & -35.83 & $-2.31 * *$ \\
\hline$(1)-(2)$ & $4.88^{*}$ & $48.57^{*}$ & 38.66 & & $22.10^{*}$ & $48.63 *$ & 19.14 & \\
\hline Barron Match 1 (3) & 33.33 & 12.11 & -18.67 & -0.32 & 44.86 & -16.49 & -56.66 & -1.62 \\
\hline$(1)-(3)$ & $-17.85 * *$ & $14.96 *$ & 33.80 & & $-6.35 * *$ & $41.73 *$ & 39.97 & \\
\hline Barron Match 2 (4) & 33.09 & 4.19 & -31.52 & -1.63 & 30.43 & -20.93 & -56.67 & $-2.02 * *$ \\
\hline$(1)-(4)$ & $-17.60 * *$ & $22.87^{*}$ & 46.66 & & $8.08 * *$ & $46.17^{*}$ & 39.98 & \\
\hline New CEO Sample & 4.18 & 11.02 & -0.77 & -0.08 & 47.58 & -2.04 & -57.42 & $-2.98 * * *$ \\
\hline Repeat Winner Sample & 24.71 & 46.40 & 30.76 & 0.66 & 31.11 & 55.85 & 23.34 & 0.48 \\
\hline
\end{tabular}

Table 7 reports the changes of accounting measures one year or three years after the announcement. We use two measures of operating performance, return on asset (ROA), and EPS growth. We test the null hypothesis that the changes are equal to zero with t-test statistics.

$* * *, * *, *$ indicate statistical significance at $0.01,0.05$ and 0.10 level, respectively. 
Table 8. Daily returns of the Best CEO sample compared to the matched samples during different market conditions

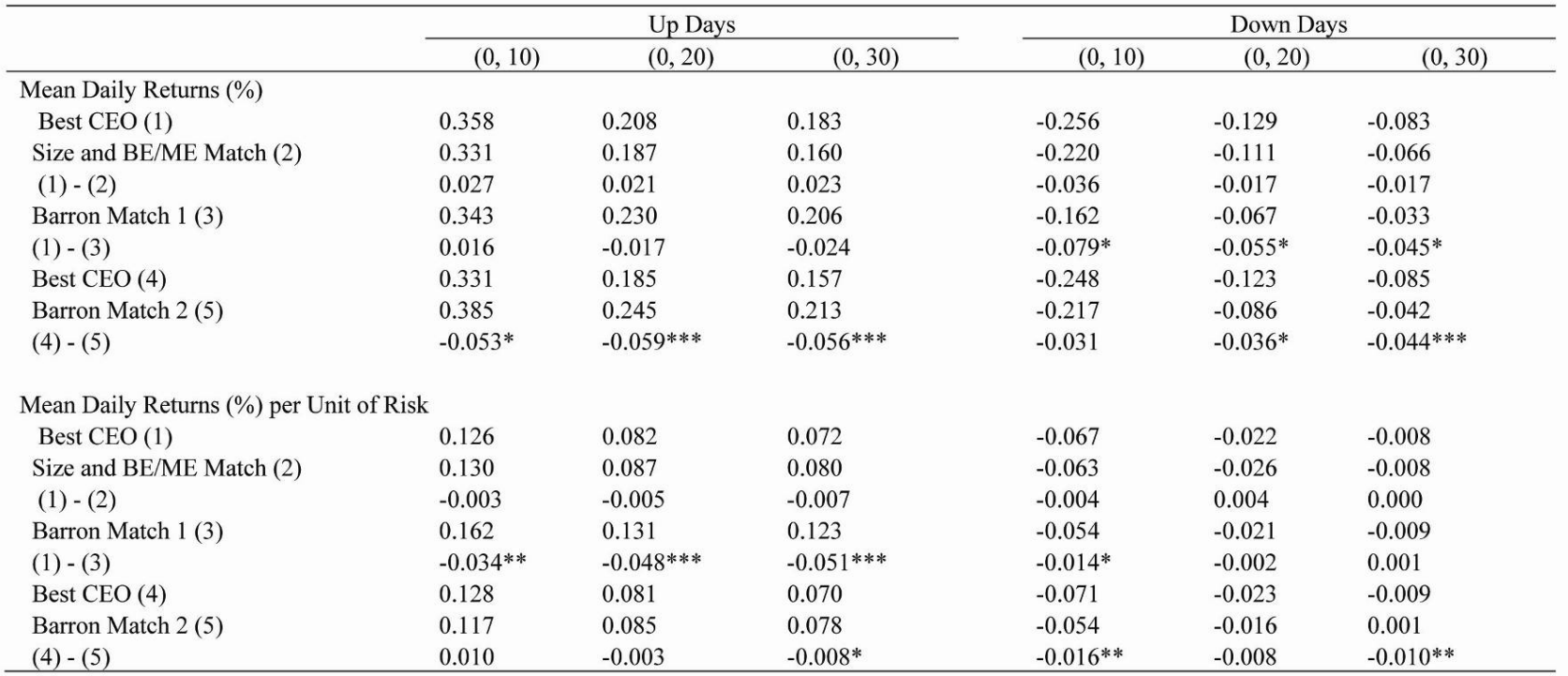

Table 8 reports the daily returns of the Best CEO sample compared to its matched samples during different market conditions. We define "up days" as the days when S\&P 500 index rose by at least 2 percent compared to its previous day index level and "down days" as the days when S\&P 500 index fell by at least 2 percent compared to previous day. From this criterion, we identified 66 up days and 80 down days in our sample period. Then, for each up day or down day, we retrieve the daily returns for both Best CEO firms and their matched firms within the period of 10 days, 20 days and 30 days, respectively after the market upturns or downturns. Then we compare the mean daily returns and the volatility of daily returns (measured by standard deviation of daily returns) of the Best $\mathrm{CEO}$ firms and their matched firms. We also calculate the mean daily returns per unit of risk by dividing the average daily return by the standard deviation of returns.

$* * *, * *, *$ indicate statistical significance at $0.01,0.05$ and 0.10 level, respectively.

Table 9. Changes of CEO compensation one year or three years after the announcement

\begin{tabular}{|c|c|c|c|c|c|c|c|c|}
\hline Sample & $\begin{array}{l}1 \text { year } \\
\text { before (1) }\end{array}$ & $\begin{array}{l}1 \text { year after } \\
\text { (2) }\end{array}$ & $\begin{array}{l}\text { Change } \\
(2)-(1)\end{array}$ & T-test & $\begin{array}{l}3 \text { years } \\
\text { before (3) }\end{array}$ & $\begin{array}{l}3 \text { years after } \\
\text { (4) }\end{array}$ & $\begin{array}{l}\text { Change } \\
\text { (4) - (3) }\end{array}$ & T-test \\
\hline \multicolumn{9}{|c|}{ Panel A. Change of CEO salary (dollars in thousands) after the announcement } \\
\hline Best CEO Sample (1) & 1,143 & 1,175 & 27 & 0.48 & 1,096 & 1,214 & 122 & $1.96^{*}$ \\
\hline Size and BE/ME Match (2) & 1,107 & 1,226 & 117 & 1.50 & 1,110 & 1,233 & 117 & $1.80^{*}$ \\
\hline (1) - (2) & 37 & -51 & -89 & & -14 & -19 & 5 & \\
\hline Barron Match 1 (3) & 766 & 666 & 60 & 1.50 & 671 & 674 & 99 & $2.66^{* *}$ \\
\hline$(1)-(3)$ & $377 * * *$ & $509 * *$ & -33 & & $425 * * *$ & $540^{* * *}$ & 23 & \\
\hline Barron Match 2 (4) & 736 & 759 & 38 & 1.53 & 702 & 764 & 82 & $3.12 * * *$ \\
\hline$(1)-(4)$ & $407 * * *$ & $417 * * *$ & -11 & & $393 * * *$ & $450 * * *$ & 40 & \\
\hline New Listing Sample & 1,187 & 1,262 & 55 & 0.50 & 1,148 & 1,288 & 155 & 1.43 \\
\hline Repeat Winner Sample & 1,106 & 1,086 & 0 & 0.00 & 1,053 & 1,138 & 90 & 1.43 \\
\hline \multicolumn{9}{|c|}{ Panel B. Change of CEO bonus (dollars in thousands) after the announcement } \\
\hline Best CEO Sample (1) & 4,069 & 2,405 & $-2,446$ & $-3.34 * * *$ & 3,986 & 1,839 & $-2,618$ & $-3.76^{* * *}$ \\
\hline Size and BE/ME Match (2) & 2,064 & 533 & $-2,063$ & $-2.03 * *$ & 2,078 & 768 & $-1,738$ & $-2.92 * * *$ \\
\hline (1) - (2) & $2,005^{*}$ & $1,872^{* *}$ & -382 & & $1,907 * *$ & $1,071^{*}$ & -880 & \\
\hline Barron Match 1 (3) & 315 & 267 & -121 & -1.00 & 382 & 120 & -330 & $-3.09 * * *$ \\
\hline$(1)-(3)$ & $3,754 * * *$ & $2,137 * * *$ & $-2,324 * * *$ & & $3,604 * * *$ & $1,719 * * *$ & $-2,288 * * *$ & \\
\hline Barron Match 2 (4) & 737 & 577 & -285 & -0.64 & 788 & 265 & -635 & $-2.50 * *$ \\
\hline$(1)-(4)$ & $3,322 * * *$ & $1,827^{* * *}$ & $-2,160 * *$ & & $3,197 * * *$ & $1,574 * * *$ & $-1,984^{* * *}$ & \\
\hline New Listing Sample & 3,432 & 2,200 & $-1,906$ & $-2.14 * *$ & 3,196 & 1,713 & $-2,034$ & $-2.17 * *$ \\
\hline Repeat Winner Sample & 4,602 & 2,614 & $-2,985$ & $-2.56^{* *}$ & 4,637 & 1,969 & $-3,202$ & $-3.09 * * *$ \\
\hline \multicolumn{9}{|c|}{ Panel C. Change of CEO total compensation (dollars in thousands) after the announcement } \\
\hline Best CEO Sample (1) & 19,670 & 15,265 & $-4,866$ & $-3.83 * * *$ & 18,784 & 13,491 & $-5,113$ & $-4.24 * * *$ \\
\hline Size and BE/ME Match (2) & 15,273 & 12,395 & $-3,280$ & $-2.12 * *$ & 13,708 & 13,025 & $-1,016$ & -1.06 \\
\hline$(1)-(2)$ & 4,397 & 2,870 & $-1,585$ & & 5,076 & 466 & $-4,097$ & \\
\hline Barron Match 1 (3) & 5,746 & 3,584 & -846 & -1.15 & 4,730 & 4,089 & 149 & 0.15 \\
\hline$(1)-(3)$ & $13,914 * * *$ & $11,681 * * *$ & $-5,383 * * *$ & & $19,110 * * *$ & $12,362 * * *$ & $-7,063^{* * *}$ & \\
\hline Barron Match 2 (4) & 6,447 & 6,548 & -224 & -0.42 & 6,233 & 6,363 & 132 & 0.24 \\
\hline$(1)-(4)$ & $13,223 * * *$ & $8,717 * * *$ & $-4,614 * * *$ & & $12,551 * * *$ & $7,128 * * *$ & $-5,245^{* * *}$ & \\
\hline New Listing Sample & 21,590 & 17,559 & $-4,348$ & $-2.53 * *$ & 18,388 & 14,594 & $-3,162$ & $-1.85^{*}$ \\
\hline Repeat Winner Sample & 18,064 & 12,917 & $-5,383$ & $-2.85^{* * *}$ & 19,110 & 12,362 & $-7,063$ & $-4.24 * * *$ \\
\hline
\end{tabular}

Table 9 reports the changes of CEO compensation one year or three years after the announcement. We use three measures of CEO compensation, CEO salary, $\mathrm{CEO}$ bonus and $\mathrm{CEO}$ total compensation. We test the null hypothesis that the changes are equal to zero with t-test statistics.

$* * *, * *, *$ indicate statistical significance at $0.01,0.05$ and 0.10 level, respectively. 